\title{
1 European norms and values and the refugee crisis
}

\author{
Issues and challenges
}

Elżbieta M. Goździak, and Izabella Main

Deaths and suffering of migrants trying to enter Europe have become one of the defining moral and political issues of our time. Many humanitarian organizations and refugee advocates argue that these deaths result from Europe's policy of exclusion and closure. Others, especially those who claim that asylum seekers, particularly Muslims, constitute a threat to 'European values' call for even stricter border controls to resolve the 'refugee crisis.'

\section{Contesting the crisis narrative}

Is it a crisis? What kind of a crisis? It certainly does not seem to be a 'refugee' crisis, because the people fleeing armed conflicts and prosecution are not the problem. Catherine Woollard, the Secretary General of the European Council on Refugees and Exiles (ECRE), posits that what is often called 'the refugee crisis' is in fact 'a deep European political crisis which unrolled in 2015/2016, paralyzing decision-making and creating deep, probably irreparable, divisions between EU Member States' (Woollard 2018: 150).

There is no denying that large numbers of asylum seekers and migrants reached Europe in recent years. According to the UN High Commissioner for Refugees (UNHCR), 34,196 refugees have risked their lives reaching Europe by sea in the first half of 2019. In previous years the numbers were much higher. In 2017, over 105,000 refugees and migrants entered Europe. In 2016, an estimated 362,000 refugees and migrants risked their lives crossing the Mediterranean Sea, with 181,400 people arriving in Italy, and 173,450 in Greece. The highest number of arrivals - 1,015,078 - was recorded in 2015. More than 800,000 of them were smuggled by sea from Turkey to Greece, and the majority continued to travel through Europe to reach Germany and Sweden. ${ }^{1}$

These are indeed large numbers, but do they constitute a 'crisis'? Today's exodus from the Middle East pales in comparison with the situation Germany faced, and surmounted, after World War II. At the end of WWII, there were some 11 million displaced people in Germany alone. They were slave laborers, prisoners of war, and Holocaust survivors. The Germans who had lived in Eastern Europe were being expelled from Czechoslovakia, 
Poland, and Hungary. The arrival of several million newcomers in Europe in recent years presents real challenges, of course, but a prosperous European Union with a population in excess of 500 million has the means to overcome them, doesn't it?

There are also those who perished in trying to reach Europe by sea. Who could forget the small, lifeless body of three-year-old Syrian toddler Alan Kurdi found on a Turkish beach in September 2015? Although the number of arrivals in Europe has drastically decreased since Alan's death, people continue to attempt the journey, and many have lost their lives in the process. According to the International Organization for Migration (IOM), between the beginning of 2014 through August 2019, close to 19,000 migrants have died trying to cross the Mediterranean and reach Europe. ${ }^{2}$ The death of each and every one of those who perished is a crisis for their loved ones, but it is also a crisis of values as governments continue to criminalize the rescue operations (HRAS 2019). As we write this introduction in August 2019, 507 migrants and refugees are stranded on two rescue vessels, which picked them up of off the coast of Libya. The UN's Refugee Agency (UNHCR) made an urgent appeal for the refugees to be allowed to disembark, calling it a 'race against time' as bad weather approaches (Squires 2019). While some are trying to rescue refugees to avert a true crisis, others continue to propagate the crisis narrative.

Reinhart Koselleck (2006) shows how 'crisis,' a concept which the Greeks used to delineate stark alternatives - right or wrong, salvation or damnation, life or death - has constantly framed modern ideas of history. Migration scholars, however, argue that face-value acceptance of crisis narratives related to recent flight of asylum seekers to Europe results in viewing and managing migration according to binary divisions: integration versus segregation, modernity versus cultural backwardness, the deserving versus the undeserving, and through the manufactured dichotomy between refugees and economic migrants (Crawley \& Skleparis 2018; McMahon \& Sigona 2018).

Cautionary lectures by migration scholars notwithstanding, politicians have certainly been exploiting the powerful narrative of 'crisis' as a political tactic. Sebastian Kurz, the Federal Chancellor of Austria and a rising star of Europe's center right, in an article published in Time magazine in 2017, invoked 'crisis' multiple times. He paired the term with phrases such as 'loss of control,' 'overwhelmed by developments,' 'a huge challenge for our country,' 'regain control,' and 'find solutions' (Kurz 2017). For Sebastian Kurz, "the "migration and refugee crisis" was not just an objective state of affairs: it was also a political tactic to present himself to a global Anglophone readership as a firm but measured state leader' (Dines et al. 2018: 440).

Viktor Orbán, the Prime Minister of Hungary, has exploited the crisis narrative to defend his draconian measures aimed not only at barring refugees from Hungary, but also at criminalizing assistance to refugees and migrants. When some 400,000, mainly Muslim, refugees and asylum-seekers crossed the Serbian-Hungarian border, and descended on the Keleti Railway 
Station in Budapest in 2015, Viktor Orbán did not see the refugees fleeing war-torn countries as a humanitarian challenge but as a Muslim invasion that required an appropriate response: closing the Balkan land route to the European Union (Goździak \& Márton 2018), and pressing the 'moral panic button' (Gerő \& Sik, this volume). His friend, Jarosław Kaczyński, the president of the Law and Justice party in Poland, has also been making the most of the crisis narrative despite the fact that, with the exception of some Chechens, there are virtually no refugees in Poland (Klaus, this volume).

Both Orbán and Kaczyński use the crisis narrative to talk about the threat that Muslim refugees pose to the Christian identity of Europe and call for protection of 'European values.' The Hungarian media likened the current 'migration crisis' to the Ottoman era "when Hungary was a "bastion," defending Christianity from "Muslim hordes"” (Pall \& Sayfo 2016: 6). Antal Rogán, at the time leader of the Hungarian Fidesz' parliamentary group, warned of a future 'United European Caliphate' (Villányi 2015), while former Secretary of State László L. Simon urged Hungarians to make more babies in order to counter the negative cultural effects of mass migration such as the envisioned 'impending victory of Islamic parties imposing polygamy and destroying the remainder of European culture' (Simon 2015: 231). These political statements have been used to strengthen the discourse about Christian identity of Europe and to portray refugees as terrorists despite the fact that neither Hungary nor Poland have ever experienced a terrorist attack, and those that launched terrorist attacks on different European cities were born in Europe. However, as Hasan (2012: 61) argues, 'propaganda against Islam and Muslims is nothing new in the West. [...] Europeans always constructed Islam as a civilizational adversary and the religion, an antithesis of European values.'

\section{What are 'European values'?}

There are multiple interpretations of 'European values.' The expression is often subject to different uses and misuses, by individuals, and institutions. The European Union and its member states refer to the EU Treaties, with the clearest expression of values in Article 2 of the Treaty of the European Union (TEU). Article 2 states: 'The EU is founded on the values of respect for human dignity, freedom, democracy, equality, the rule of law, and respect for human rights, including the rights of persons belonging to minorities' (TEU). These quintessentially democratic values are shared by other democracies outside the European Union, and outside the European continent - countries like New Zealand, and Canada come immediately to mind - therefore calling them 'European values' seems a little presumptuous.

Recently, 'European values' have been invoked both to support refugees and migrants and to attack them. On one hand, demagogues such as Viktor Orbán have positioned themselves as defenders of a Christian Europe, and enacted anti-migrant policies to protect Europe from being overrun by 
Muslims. On the other hand, humanitarians often appeal to a vision of Europe 'As a community of nations that has overcome war and fought totalitarianism' (Barroso 2012). In his acceptance speech of the Nobel Peace Prize on behalf of the EU in 2012, José Manuel Barroso (2012), President of the European Commission, assured his audience that the European community 'will always stand by those who are in pursuit of peace and human dignity.'

Daniel Trilling (2018) asserts that the visions of Europe promulgated by Orbán and Barroso are wrong. Orbán's rendition omits the fact that Europe is a diverse continent, in which Christian, Muslim, Jewish, and secular traditions have been present for centuries. Orbán's vision also claims that refugees and asylum seekers present a threat to 'European' traditions of tolerance, freedom, and democracy. History reminds us that these principles have been fought for and won, usually against the violent resistance of European elites. Ironically, many of the refugees seeking safe haven in Europe have struggled for the same values and rights in their home countries.

The vision endorsed by humanitarians such as Barroso presents Europe as a beacon of hope to the rest of the world. Trilling (2018) argues that Europe is in the position to affect the world for better or worse and pressing politicians to live up to such an ideal is certainly worthwhile. However, he further argues:

The aspiration will remain unfulfilled if we ignore the fact that while the nations of Europe have overcome war and fought totalitarianism, many of these same nations became rich and powerful by conquering and administering huge empires, which were partially justified by the idea of European racial supremacy. And European unity, in its founding documents, was conceived of as a way of maintaining imperial power, as well as preventing future conflict in Europe.

(Ibid. 2018)

Let's not forget the history of Europe. Let's also remember that European racism is not a thing of the past and that Europeans need continued education about racism, and skills to fight it (see Mosse, this volume).

\section{Which values are at risk?}

Taking stock of the actions implemented to solve the Mediterranean crises and the wider European political crisis on migrant and refugee protection, Catherine Woollard (2018) concludes that the solutions seriously undermined Europe's values, both directly and indirectly. 'Human dignity is clearly absent in the conditions in which refugees and migrants find themselves in Europe and in the countries in which they are stuck as a result of European action,' she writes (Woollard 2018: 151). In this volume, several 
authors provide examples of lack of respect for human dignity. In Ventimiglia, local politicians on both sides of the Italian-French border, have created a hostile environment, where the presence of migrants was not welcomed and attempts were made to encourage the disappearance of migrants from the area by denying them housing spaces, prohibiting food distribution, and expelling them from the territory of the city (Aris Escarcena, this volume). In Germany, the Willkommenskultur approach to refugees early on (Hermann, this volume) has shifted and detentions and deportations have increased resulting in a polarized nation fearful that more migration will lead to a greater divide in society (Günther, this volume).

Human dignity is also undermined in the ways refugees and migrants are portrayed by the media, and by politicians. Migration is often discussed in military terms - words and phrases such as invasion, threat, defense of borders - are used along with either openly or insidiously racist or Islamophobic commentaries. Framing the current 'refugee crisis' as a security threat is part of a broader and older attempt to portray migration across international borders as a security risk. Once it was announced that the nineteen hijackers, who attacked the Twin Towers in New York City, the Pentagon in Washington, DC, and crashed a plane in Shanksville, Pennsylvania, were foreign nationals, those critical of the U.S. immigration system argued that the government must use all available means to protect the national security of the country. The critics called for 'enhancing and enlarging the border security functions of the Immigration and Naturalization Service (INS)' (Chebel d'Appollonia 2012: 1). Within a few days, the Immigration and Nationality Act was adopted, and a series of reforms aimed at implementing immigration restrictions, including detention of foreign-born individuals without charge, began.

Terrorist attacks in Paris, Brussels, and Niece have sparked similar assertions in Europe despite the fact that the terrorists were French and Belgian citizens. Facts notwithstanding, policy-makers on both sides of the Atlantic allege that human smuggling and human trafficking are a conduit for international terrorism. On September 20, 2001, the Council of the European Union called for strengthening of surveillance measures, including vigilance in issuing residency permits, and systematic checking of identity papers, under article 2.3 of the Schengen Convention. The bombings of Madrid on March 11, 2004 and London on July 7, 2005 further consolidated the national security policies in Europe.

However, these anti-immigrant sentiments and conceptualizations of migrants as criminals and terrorists predate the terrorist attacks by at least a decade or more. In the 1990s, conservative discourses identified multiculturalism as a cause of societal disintegration. The best-known version of this kind of discourse is Huntington's The Clash of Civilizations (1996). It mediates the differentiation between us and them by identifying other peoples and cultures that endanger the survival of the home culture. Migration is identified as being one of the main elements weakening national tradition 
and threatening societal homogeneity. The current debates in Europe (and elsewhere) also contribute to 'othering' refugees and migrants, which is another way to strip people of their dignity.

The human rights that are not respected start with the most basic and most important right: the right to life, which is undermined by the ceasing and disruption of search and rescue missions, and criminalization of assistance to asylum seekers. As Aris Escarcena writes in this volume, in extreme cases, such as that of Cedric Herrou, a French farmer who provided support to migrants in the border area between France and Italy, volunteers were convicted for 'crimes of solidarity' (Tazzioli \& Walters 2019). Carola Rackete, the German captain of a humanitarian rescue ship with 40 migrants aboard, was arrested in June 2019, after she rammed her vessel into an Italian border police motorboat while docking at a tiny Mediterranean island in defiance of Italy's anti-migrant interior minister, Mateo Salvini. German Foreign Minister Heiko Maas criticized the Italian decision to arrest the captain. 'Saving lives is a humanitarian duty,' he said on Twitter. 'Rescue at sea must not be criminalized. It's up to the Italian justice system to swiftly resolve the allegations' (D’Emilio \& Jordans 2019).

Other freedoms are also being undermined. Freedom from torture is violated by the containment of people in Libya, where the horrific conditions are well known (Dambach 2019). The right to asylum in Europe is in danger; asylum seekers often cannot reach the European Union or are prevented from submitting asylum claims (Pech et al. 2018; Klaus, this volume). However, one of the greatest challenges facing policy-makers in Europe concerns the rule of law. The rule of law has been deteriorating in some European countries, with Hungary and Poland as the biggest offenders, and the four Visegrad countries refusing to participate in the relocations scheme (EC 2018).

It is obvious that the European Union will not be able to function properly without some level of solidarity between and among member states. As Catherine Woollard (2018: 156) wrote:

The idea of the EU as a normative power is being undermined. The idea of normative power is either that the EU is a model which others follow through choice rather than through the use of force, or that it is a promoter of its values in the world, gaining credibility through the implementation of those values in its own territory. In either sense, the crisis on the migration and refugee issue has damaged normative power.

\section{The contributions}

It is against these issues and challenges that the project on Norms and Values in the European Migration and Refugee Crisis (NoVaMigra) has been undertaken by eight universities in eight different countries: France, Germany, Greece, Hungary, Italy, the Netherlands, Poland, and Sweden. The present 
volume is the first product of the research we are conducting aimed at general readership, not just policy-makers in Brussels.

The contributors look at existing challenges and solutions for seamless integration of refugees, asylum seekers, and migrants in the eight countries. They discuss both European and national values and analyze activities undertaken by national and local actors. The volume is divided into four distinct but inter-related thematic strands that address and reflect upon different aspects of the migration crisis and values nexus.

The first strand considers the effects of xenophobia and racisms on attitudes towards refugees and the resulting moral panic. These anti-values are contrasted with the role of historical memory of forced displacement in forming contemporary attitudes towards migrants. In her paper based on oral testimonies collected from inhabitants of the Greek island of Lesvos, Marilena Anastasopoulou unpacks the fluid relationship between history, memory, identity, and values and the way they inform assistance to migrants and refugees today. Bernard Mossé also draws on history, this time the history of the Holocaust. Using the Foundation of the Camp des Milles in France, a memorial site for a camp used for interments and deportations from September 1939 to 1942 , as a case study, he describes the experiences of defending democratic values through educational and training programs for French citizens and visitors to the camp focused on racism and xenophobia, the promotion of hospitality to, and solidarity with refugees. This is a valuable contribution to the volume from a practitioner's point of view. Deploying the theoretical framework of the moral panic developed by Stanley Cohen (1972), Márton Gerő and Endre Sik analyze the construction of the moral panic button in Hungary to portray refugees and immigrants as a threat to the European values.

The second theme coalesces around restricting access to the European continent by erecting barbed wire fences, detaining asylum seekers, and deporting not just irregular migrants, but also those seeking safe haven. Writing about the abuse of human rights and the de facto abolition of the institution of asylum in Hungary, Felix Bender asks why there is little resistance to this situation by states that seemingly cherish the normative principle underlying the right to seek asylum. Bender argues that core EU states profit from the fact that countries at the EU periphery, such as Hungary, are keeping refugees at bay. He provocatively contends that this 'division of labor' allows Hungarian politicians to reap the political fruits of demonizing refugees, while simultaneously enabling core EU states, such as Germany, to foster the image of states upholding the right to asylum. Witold Klaus deconstructs the values underpinning Polish migration policy by analyzing legal and bureaucratic activities undertaken by Polish authorities after 2015. He juxtaposes the policies that focus on securitizing migration and closing borders to refugees, while at the same time accepting large numbers of Ukrainian labor migrants. Analyzing portraits of deportation detention in the German media, Johanna C. Günther maps out the values, actors, and their actions that shape German asylum policy. 
The analysis shows a shift in the socio-political climate in Germany: from a country that welcomed refugees to a highly polarized nation fearful that more migration will lead to a greater divide in society.

The third topic focuses on the role national and municipal governments play in the integration of refugees in France, Germany, the Netherlands, Spain, Sweden, and the United Kingdom. The cities of Paris and Barcelona serve as case studies interrogating policies and actions at the local level. In the opening chapter, Myriam Hachimi Alaoui \& Janie Pélabay analyze integration contracts, Contrat d'Accueil et d'Intégration and the Contrat d'Intégration pour la Famille, aimed at ensuring public promotion of the 'values of the Republic' among newcomers eligible for residence permits, whether they be migrants or refugees. These programs are part and parcel of the 'civic turn' (Mouritsen \& Jørgensen 2008) in immigration and integration policies implemented in a variety of European countries starting in the late 1990s. Their analysis is based on field research in Paris and Lille conducted between 2012 and 2015. Robert Larruina and Halleh Ghorashi also use empirical research to investigate the role of migrants and refugees in the European Migrant Advisory Board (EMAB). This chapter builds on their previously published studies (Ghorashi 2010; Larruina, Boersma, \& Ponzoni 2019) and asks a very important question: What are the challenges and opportunities of including refugees' perspectives in EU policy? Comparing Paris and Barcelona, Louise Hombert takes a close look at the rhetoric the mayors of these cities have mobilized to talk about reception of migrants. Both metropoles call themselves 'refuge cities,' but given their very different migration situations and political contexts, Hombert asks whether being a 'refuge city' has the same meaning and the same stakes for both Paris and Barcelona. Roberto Scaramuzzino and Brigitte Suter spotlight Swedish community-based organizations (CBOs) that have been very active during the 'refugee crisis' of 2015 and discuss their value-based advocacy aimed at affecting migration policy-making in Sweden. As Brexit hangs in the balance and the politics spiral out of control in the United Kingdom, Joanne van Selm looks at community-based sponsorship for refugees. Her chapter tries to answer the following core questions: how can we conceptualize participation in community sponsorship efforts from a values perspective? How could sponsorship of refugees by a few spread those values to, or strengthen those values in others in society? How can tolerance be understood, and developed, in a country where immigration has happened more quickly than its core citizenry has managed to adapt to it? In her chapter, Therese Hermann, looks at the mobilization of large-scale support for incoming refugees within the framework of Willkommenskultur. She argues that the volunteers' focus on diversity and sustaining local networks are better understood within a framework of care ethics, rather than humanitarianism.

The final thematic strand centers on practicing pro-migration values in different national and local contexts. Christian Fernández opens the fourth part of the book by looking at Swedish cosmopolitanism and the evolution of the country's immigration policy in the post-2015 period. He wonders 
what the changes in the immigration policy mean and asks whether we are witnessing the break-up of the Swedish model of immigration. Turning her attention to Italy, Chiara Marchetti asks: what happens when a regime of rights is substituted by a regime of deservingness? What do Italian institutions expect from migrants, and vice versa? How do social workers mediate these possibly conflicting expectations? She examines how asylum seekers and social workers struggle for recognition as the way to deal with Others at the nexus where models based on rights, deservingness, and control operate, and where 'refugees' are more and more considered to be 'irregular economic migrants' and must increasingly demonstrate that they are not. Juan Pablo Aris Escarcena takes us to Ventimiglia, the Italian coastal town closest to France. The border between Italy and France has become a hostile environment, a result of political measures of both states. Using his ethnographic research in Ventimiglia, Escarcena analyzes how the local Catholic parish supported mobilization of volunteers by appealing to fundamental values of civil society in the town where refugees gathered in the hope of getting access to France. In the final chapter of this section, Izabella Main takes a look at Poznań, a city in Western Poland, to juxtapose the anti-refugee narrative promulgated by the current Law and Justice government in Poland with policies and practices, underscored by pro-immigration values, at the local level. The activists she interviewed to inform this chapter had two goals: 1) to support refugees and migrants (in Poland and abroad) and 2) to educate and mobilize Polish society to counterbalance negative discourse supported by the government and state media. The result of the first was, as she points out, a proverbial 'drop in the bucket.' Assessing the outcomes of actions aimed at social change is methodologically and epistemologically difficult, and requires a long-term perspective.

The volume ends with short Conclusions where Elżbieta M. Goździak and Brigitte Suter identify possible solutions and improvements needed to step away from the crisis narrative in order to facilitate lasting integration of different types of migrants.

\section{Notes}

1 See UNHCR website www.unhcr.org/europe-emergency.html

2 See IOM Missing Migrants Project website https:/missingmigrants.iom.int/

\section{References}

Barroso, J. M. (2012). Nobel Peace Prize Speech. Available at: https:/europa.eu/ rapid/press-release_SPEECH-12-930_en.htm

Chebel d'Appollonia, A. (2012). Frontiers of Fear. Immigration and Insecurity in the United States and Europe. Ithaca: Cornell University Press.

Cohen, S. (1972). Folk Devils and Moral Panics. London: MacGibbon \& Kee. 
Crawley, H. \& Skleparis, D. (2018). 'Refugees, migrants, neither, both: Categorical fetishism and the politics of bounding in Europe's "migration crisis," Journal of Ethnic and Migration Studies 44(1), pp. 48-64.

Dambach, K. (2019). 'New images of tortured migrants emerge from Libya,' InfoMigrants, 1 March. Available at: www.infomigrants.net/en/post/15467/new-images-of-tortured-m igrants-emerge-from-libya

D'Emilio, F. \& Jordans, F. (2019). 'Migrant aid ship captain arrested after ramming italian police boat,' Huffington Post, 29 June. Available at: www.huffpost.com/entry/ italian-aid-migrant-ship-captain-arrested_n_5d1825dce4b082e5536a6f08

Dines, N., Montagna, N., \& Vacchelli, E. (2018). 'Beyond crisis talk: Interrogating migration and crises in Europe,' Sociology 52(3), pp. 439-447.

EC (European Commission) (2018). Relocation: Commission Launches Infringement Procedures against the Czech Republic, Hungary and Poland. Available at: https:// europa.eu/rapid/press-release_IP-17-1607_en.htm

Ghorashi, H. (2010). 'The right to be different: The position of Muslim migrants in the Netherlands,' in Banakar, R. (ed.), Rights in Context: Law and Justice in Late Modern Society. Surrey: Ashgate, pp. 163-177.

Goździak, E. M. \& Márton, P. (2018). 'Where the wild things are: Fear of Islam and the anti-refugee rhetoric in Hungary and in Poland,' Central and Eastern European Migration Review 7(2), pp. 125-151.

Hasan M. (2012). 'Feminism as Islamophobia: A review of misogyny charges against Islam,' Intellectual Discourses 20(1), pp. 55-78.

Huntington, S. P. (1996). The Clash of Civilizations. Touchstone: New York.

HRAS (Human Rights at Sea) (2019). Briefing Note. Legal and Policy Matters arising from the Increased Criminalization of Civil Society Search and Rescue Activities in the Mediterranean. Available at: https:/safety4sea.com/wp-content/uploads/2019/02/ HRAS-Legal-and-Policy-Matters-Arising-from-the-Increased-Criminalisation-of-theCivil-Society-Search-and-Rescue-Activities-in-the-Mediterranean-2019_02.pdf

Koselleck, R. (2006). 'Crisis,' Journal of the History of Ideas 67(2), pp. 357-400.

Kurz, S. (2017). 'Only by regaining control can we solve the migration and refugee crisis,' Time, 18 December. Available at: http://time.com/5068561/sebastian-kurz-a ustria-chancellormigrant-crisis/

Larruina, R., Boersma, K., \& Ponzoni, E. (2019). 'Responding to the Dutch asylum crisis: Implications for collaborative work between civil society and governmental organizations,' Social Inclusion 7(2), pp. 53-63.

McMahon, S. \& Sigona, N. (2018). 'Navigating the Central Mediterranean in a Time of "Crisis": Disentangling Migration Governance and Migrant Journeys,' Sociology 52(3), pp. 497-514.

Mouritsen, P. \& Jørgensen, K. E. (eds) (2008). Constituting Communities. Political Solutions to Cultural Conflict. Basingstoke: Palgrave Macmillan.

Pall, Z. \& Sayfo, O. (2016). 'Why an Anti-Islam Campaign Has Taken Root in Hungary, a Country with Few Muslims,' Revue, 14. September. Available at: http://visegra drevue.eu/why-an-anti-islam-campaign-has-taken-root-in-hungary-a-coun try-with-few-muslims/

Pech, T., Tran Thiet, J.-P., \& Rial, J.-F. (2018). Saving the Right to Asylum. [Report]. Paris: Institut Montaigne. Available at: www.institutmontaigne.org/en/publications/ saving-right-asylum 
Simon, L. (2015). Szaporodjunk! Népszabadság. [Video]. 5 September. Available at: http:// nol.hu/video/lsimon-a-szaporodasban-latja-a-jovot-1573295?utm_source=mandiner\& utm_medium=link\&utm_campaign=mandiner_201601

Squires, N. (2019). 'UN urges Europe to allow 500 migrants stranded on rescue boats to be allowed to come ashore,' The Telegraph, 13 August. Available at: www.telegrap h.co.uk/news/2019/08/13/un-urges-europe-allow-500-migrants-stranded-rescue-boats-al lowed/

Tazzioli, M. \& Walters, W. (2019). 'Migration, solidarity and the limits of Europe,' Global Discourses 9(1), pp. 175-190.

TEU (Treaty of the European Union). Article 2. Available at: https:/eur-lex.europa. eu/legal-content/EN/TXT/?uri=celex $\% 3$ A12012M\%2FTXT

Trilling, D. (2018). Five myths about the refugee crisis. The Guardian, June 5. Available at: www.theguardian.com/news/2018/jun/05/five-myths-about-the-refugee-crisis

Villányi, K. (2015). Azt Akarjuk, Hogy Unokáink egy Európai Kalifátusban Éljenek? Magyar Idök, 14 November. Available at: http://magyaridok.hu/belfold/azt-akarju k-hogy-az-unokaink-egy-europai-kalifatusban-el-jenek-5035/

Woollard, C. (2018). Has the Mediterranean refugee crisis undermined European values? IEMed Mediterraneum Yearbook 2018, pp. 150-156. 